\title{
Analisis Graph Clustering Terhadap User Behavior Di Official Account Facebook Universitas Bina Darma Palembang
}

\author{
Ayu Gahardina1, Ilman Zuhri Yadi ${ }^{2}$ \\ ${ }_{1}^{1}$ Informatics Departement, Bina Darma University, Palembang, Indonesia \\ ${ }^{2}$ Information System Departement, Bina Darma University, Palembang, Indonesia \\ Email: ayugahardina@gmail.com¹, Ilmanzuhriyadi@binadarma.ac.id²
}

\begin{abstract}
At a time when the times are increasing, it cannot be denied that almost some people use social media as a means of communication. Not only is it a means of communication, even social media is a place to show their habits. Without realizing it, the more information that is spread on social media regarding selfinformation, it will make information that can benefit others. User Behavior Analytics as defined by Gartner is a cybersecurity process of detection of insider threats, targeted attacks and financial fraud. The UBA solution looks at patterns of human behavior, and then applies algorithms and statistical analysis to detect meaningful anomalies of those patterns. Gephi as an open source network visualization platform that can be used to analyze various cases using graph visualization. One of these analyzes can be done by using data that has been scraped from social media, Facebook, social media, Bina Darma University to get data visualization of the cases being tested. From these results, the graph clustering process is carried out in Gephi to obtain data clusters. The results will then be analyzed and identified so that they can become material for information about social media user behavior.
\end{abstract}

Keywords: User Behavior Analytic, Graph Clustering, Social Media

\section{PENDAHULUAN}

Saat ini seluruh orang di penjuru bagian dunia sudah terletak di kehidupan internet. Dari berbagai kalangan,nyaris sebagian besar pengguna internet mengakses media sosial. Media sosial pun sekarang bukan lagi menjadi fenomena baru di era internet ini.Banyak keuntungan dan kemudahan yang diperoleh setiap pengguna media sosial untuk memenuhi segala kebutuhannya. Seperti halnya Boyd dan Ellison, Media sosial merupakan layanan berbasis web yang memungkinkan individu 
Vol. 1, No. 2, May 2020 e-ISSN: 2775-2496

https://journal-computing.org/index.php/journal-cisa/index

membangun profil dalam sistem yang terbatas, berhubungan dengan pengguna lain untuk berbagi informasi, dan melihat profil pengguna lain di dalam sistem tersebut [1].

Popularitas sosial media dalam sebagian tahun terakhir semenjak awal kali diketahui di akhir 1990- an terus menjadi bertambah paling utama Facebook. Perihal ini diakibatkan sebab sosial media sanggup menghubungkan ratusan juta manusia di segala dunia tanpa memahami batas geografis [2]. Tidak hanya itu pula, yang menimbulkan popularitasnya bertambah di mata pengguna merupakan terdapatnya perbandingan antara sosial media serta taman website tradisional yang sangat signifikan. Taman website tradisional secara garis besar diorganisasi dengan berorientasi pada konten, sebaliknya sosial media diorganisir bersumber pada pengguna beserta preferensinya [3].

Sosial media spesialnya Facebook menangkap data- data yang berkaitan dengan orang lewat account profil, interaksi antar pengguna secara langsung ataupun lewat tim, serta konten yang disukai ataupun dibagikan. Dataset tersebut bisa didapat dengan memakai aplikasi yang ada buat memperoleh (scrapting) informasi Facebook. Cuma saja data set dalam dalam jumlah besar nyaris susah didapatkan sebab Facebook sudah mempraktikkan sebagian pengaturan pribadi pada informasi penggunanya, sehingga informasi yang didapat cuma sebatas data-data dari pengguna yang mempunyai ikatan pertemanan dengan pengguna scrapting [4].

Popularitas serta besarnya informasi yang dihasilkan serta tersedianya informasi tersebut secara publik membagikan kesempatan sekalian tantangan untuk periset buat melaksanakan riset terpaut analisis sosial media, misalnya User Behavior dalam skala besar lewat aktivitasnya di sosial media. Analisis sosial media bisa dicoba dengan gampang dengan tersedianya bermacam berbagai tools semacam NetMiner, UCINet, muxViz, serta Gephi yang sediakan framework buat bermacam tipe analisis sosial media semacam pencarian, analisis bacaan, analisis visual serta aplikasi sensor [5]. Tersedianya informasi dari sosial media serta banyaknya tools yang dapatt digunakan dalam pengolahan informasi sosial media hendak memesatkan penyajian hasil analisis sosial media. Pada riset ini, periset memilih Gephi sebab Gephi ialah tools analisis jaringan serta fitur lunak visualisasi paket open source serta perlengkapan ini dirancang buat memetakan grafik sehingga bisa jadi pemecahan sempurna buat menunjukkan jaringan serta ikatan link. Visualisasi 
Vol. 1, No. 2, May 2020 e-ISSN: 2775-2496

https://journal-computing.org/index.php/journal-cisa/index

memiliki salah satu kelebihan yaitu dapat menunjukkan kedua koneksi hubungan dan metrik lainnya pada waktu yang sama.

Berdasarkan permasalahan diatas maka peneliti akan meneliti mengenai analisis user behavior terhadap pengguna Facebook di Official account Facebook Universitas Bina Darma Palembang dengan cara melakukan visualisasi social graph untuk melihat keterkaitan sosial (sociometric) antar pengguna

\section{METODOLOGI PENELITIAN}

\subsection{Proses Penelitian}

Pada penelitian ini, data yang akan digunakan diperoleh dari jaringan sosial digital Facebook official Universitas Bina Darma Palembang. Data tersebut meliputi ikatan dan simpul. Ikatan menggambarkan hubungan antar user dengan pengguna berupa like dan comment dari pengguna fanpage dan grup tersebut, sedangkan simpul menggambarkan fanpage dan topik yang dibahas. Data ini didapatkan menggunakan tools yang dimiliki oleh bahasa pemrograman python yaitu Facebook Scraper. Facebook Scraper ini dapat melakukan scrapting data yang dimiliki oleh akun facebook maupun grup yang ada pada facebook. Format standar yang digunakan pada data ini adalah comma separated file (CSV).

Hal yang paling utama pada penelitian ini adalah untuk menganalisis user behavior berdasarkan official account facebook yang dimiliki Universitas Bina Darma Palembang. Oleh sebab itu, identifikasi dari cluster dalam jaringan adalah poin utama dalam penelitian ini. Statistik yang digunakan adalah modularity (kekuatan pembagian sebuah jaringan menjadi beberapa cluster) untuk medeteksi tiap-tiap simpul masuk ke dalam cluster tertentu sehingga bisa dibedakan warnanya tiap komunitas/cluster. Berikut tahapan-tahapan yang akan dilakukan pada penelitian kali ini:

1) Download software yang akan digunakan untuk menunjang proses penelitian, seperti menginstall bahasa pemrograman python dalam proses scrapting data pada official account facebook, dan juga bahasa pemrograman java yang berguna untuk menjalankan aplikasi visualisasi gephi.

2) Kemudian melakukan scrapting data menggunakan Facebook Scraper yang ada pada bahasa pemrograman python. Sebelum itu, kita diharuskan untuk menginstall pip terlebih dahulu agar dapat menjalankan Facebook Scraper tersebut. 
3) Setelah proses scrapting data, dihasilkan data 100 postingan teratas yang berupa post_id, text, post_text, shared_text, time, image, video, likes, comment, shared, post_url, dan link.

4) Dikarenakan data yang dihasilkan terlalu banyak dan akan sulit bila dipahami apabila langsung diproses ke dalam visualisasi data, maka dilakukan proses cleaning data terlebih dahulu dan hal yang akan diproses yaitu hanya banyaknya likes dan comment yang dihasilkan saja.

5) Kemudian setelah proses cleaning data selesai, dapat langsung dilakukan proses visualisasi data menggunakan aplikasi gephi untuk mengetahui kecenderungan user behavior yang terbentuk dengan melihat nodes dan edges yang dihasilkan oleh data.

\subsection{Pengelohan Data}

Software Gephi adalah sebuah aplikasi yang bersifat open source untuk melakukan eksplorasi dan manipulasijaringan. Sebuah modul jaringan yang akan dikembangkan dapat diolah dengan diimpor, divisualisasikan,dipetakan, di-filter, dimanipulasi dan diekspor di dalam software Gephi tersebut [6]. Gephi yaitu analisis jaringan dan perangkat lunak visualisasi paket open source yang ditulis didalam bahasa pemrograman Java pada platform NetBeans. Alat ini dirancang agar dapat memetakan grafik sehingga dapat digunakan sebagai solusi ideal untuk menampilkan jaringan dan hubungan link. Salah satu aspek keren dari visualisasi yaitu dapat menunjukkan kedua koneksi hubungan dan metrik lainnya pada waktu sama [7].

\section{RESULTS AND DISCUSSION}

\subsection{Hasil Penelitian}

Setelah melakukan scrapting data pada fanpage dan grup di official account Universitas Bina Darma Palembang didapatkan data yang abstrak. Sehingga dilakukan cleaning data untuk memudahkan dalam proses visualisasi aplikasi dan cluster yang terbentuk lebih mudah dibaca dan dipahami. Data yang didapatkan saat scrapting sebanyak 100 entitas. Berikut adalah scrapting data yang sudah melalui proses cleaning.

Tabel 1. Top 20 data fanpage dengan jumlah likes terbanyak

\begin{tabular}{|l|l|l|}
\hline Topik & Likes & comment \\
\hline Pengumuman & 3416 & 2 \\
\hline
\end{tabular}


Journal of Computer and Information Systems Ampera

Vol. 1, No. 2, May 2020 e-ISSN: 2775-2496

https://journal-computing.org/index.php/journal-cisa/index

\begin{tabular}{|l|l|l|} 
Promosi Diskon & 2755 & 6 \\
\hline Promosi Diskon & 2321 & 1 \\
\hline Ucapan & 2100 & 7 \\
\hline Ucapan & 1263 & 36 \\
\hline Ucapan & 487 & 1 \\
\hline Video Promosi & 271 & 0 \\
\hline Promosi Diskon & 219 & 34 \\
\hline Ucapan & 96 & 0 \\
\hline Promosi Diskon & 95 & 9 \\
\hline Video Promosi & 94 & 9 \\
\hline Seminar & 84 & 0 \\
\hline Seminar & 83 & 16 \\
\hline Promosi Diskon & 70 & 1 \\
\hline Video Promosi & 62 & 1 \\
\hline Informasi Umum & 58 & 0 \\
\hline Promosi Diskon & 58 & 3 \\
\hline Promosi Diskon & 55 & 1 \\
\hline Video Promosi & 55 & 0 \\
\hline Informasi Umum & 54 & 0 \\
\hline & &
\end{tabular}

Tabel 2. Top 20 data grup dengan jumlah likes terbanyak

\begin{tabular}{|l|l|l|}
\hline topik & likes & comment \\
\hline Share Informasi & 45 & 1 \\
\hline Status Anggota & 34 & 6 \\
\hline Share Informasi & 21 & 2 \\
\hline Share Informasi & 17 & 1 \\
\hline Share Informasi & 16 & 0 \\
\hline Share Informasi & 16 & 7 \\
\hline Share Informasi & 13 & 0 \\
\hline Share Informasi & 13 & 0 \\
\hline Share Informasi & 12 & 0 \\
\hline Share Informasi & 12 & 0 \\
\hline Share Informasi & 11 & 0 \\
\hline Share Informasi & 10 & 0 \\
\hline Share Informasi & 10 & 0 \\
\hline Share Informasi & 10 & 0 \\
\hline Share Informasi & 10 & 0 \\
\hline Promosi & 10 & 0 \\
\hline Promosi & 10 & 0 \\
\hline
\end{tabular}


Vol. 1, No. 2, May 2020 e-ISSN: 2775-2496

https://journal-computing.org/index.php/journal-cisa/index

\begin{tabular}{|l|l|l|} 
Share Informasi & 10 & 0 \\
\hline Share Informasi & 10 & 0 \\
\hline Promosi & 10 & 0 \\
\hline
\end{tabular}

Pada Tabel 1 dapat dilihat bahwa pada fanpage Universitas Bina Darma Palembang, hal yang paling diminati oleh penggunanya adalah topik bahasan tentang Pengumuman dan Promosi diskon. Banyaknya jumlah likes pada kedua kategori ini menunjukkan bahwa pengikut fanpage ini lebih tertarik dan antusias terhadap pengumuman perkuliahan dan promosi diskon yang diberikan oleh Universitas Bina Darma Palembang. Dilihat dari kebiasaan tersebut, mayoritas yang menyukai topik tentang pengumuman perkuliahan adalah Mahasiswa Universitas Bina Darma sendiri dan yang menyukai topik tentang promosi diskon adalah calon mahasiswa baru yang ingin mendaftar ke Universitas Bina Darma Palembang. Hal ini menunjukkan bahwa sebelum calon mahasiswa mendaftar ke Universitas Bina Darma Palembang, mereka melakukan riset informasi terlebih dahulu mengenai Universitas yang akan mereka tuju.

Kemudian pada Tabel 2 diatas terlihat bahwa kegiatan/topik yang sering dibahas pada grup facebook Universitas Bina Darma Palembang adalah sharing informasi mengenai Universitas Bina Darma dan status yang dibuat oleh para anggota pada grup. Sehingga antusias anggota grup banyak mengenai informasi penting yang dapat menunjang kegiatan perkuliahan di Universitas Bina Darma Palembang serta status yang dibuat juga dapat meningkatkan semangat antusiasme anggota grup. Setelah mendapatkan data yang telah di-cleaning, selanjutnya kita melakukan visualisasi data dengan menggunakan aplikasi gephi. Visualisasi data ini berguna untuk mempermudah pengguna untuk melihat hubungan antar user dengan pengguna berupa like dan comment dari pengguna fanpage dan grup tersebut. Berikut dibawah ini adalah hasil dari visualisasi data dengan menggunakan aplikasi gephi:

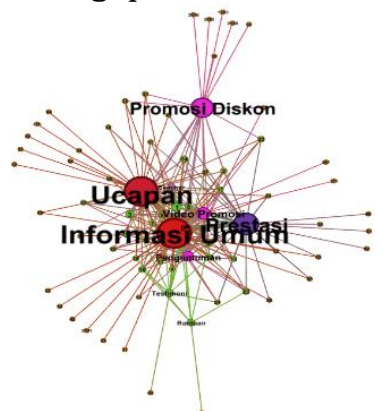

Gambar 1 Hasil visualisasi halaman facebook UBD 


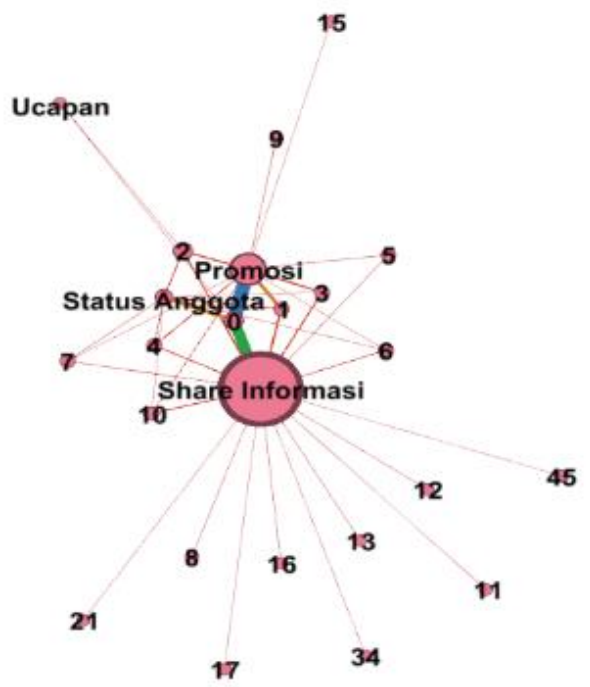

Gambar 2. Hasil visualisasi grup facebook UBD

Berdasarkan pada gambar diatas, terlihat hubungan yang terbentuk di setiap entitas. Sehingga terdapat sebuah cluster yang dapat menunjukkan sebanyak apa interaksi antar pengguna dengan topik yang dibahas. Semakin besar modularity pada cluster, maka semakin besar populasi yang terbentuk. Pada hasil visualisasi data fanpage official facebook Universitas Bina Darma Palembang di atas, terdapat sejumlah nodes dan edges yang terbentuk. Nodes yang didapat sebesar 79 nodes dan jumlah edges yang didapat sebesar 208 edges. Setiap nodes bisa memiliki lebih dari 1 edges menyesuaikan keterkaitan antar modul yang terbentuk. Di bawah ini adalah jumlah nodes dan edges yang terbentuk.

\section{Context $\mathrm{X}$ \\ Nodes: 79 \\ Edges: 208 \\ Undirected Graph}

Gambar 3. Jumlah nodes dan edge fanpage facebook UBD 


\subsection{Pembahasan}

\section{1) Visualisasi Data Pada Halaman Facebook}

Pada saat penelitian ini dilakukan, fanpage Universitas Bina Darma Palembang sudah memiliki pengikut sebanyak 15.504 orang dan jumlah total likes yang dimiliki berjumlah 15.140 likes. Pada gambar 4.1 menunjukkan visualisasi data dari 100 postingan teratas pada fanpage Universitas Bina Darma Palembang. Semakin besar diameter node dan edges menunjukkan terbentuknya cluster sosial dimana sejumlah fanpage di-like oleh beberapa user tertentu yang membentuk suatu cluster secara tidak langsung. Dapat terlihat dengan jelas bahwa terdapat 5 cluster sosial yang terbentuk. Selain itu terlihat pula bahwa cluster yang berwarna merah dan oren yang menunjukkan bahwa topik tersebut memilik jumlah likes terbanyak. Semakin besar node yang terbentuk, maka semakin besar jumlah populasinya. Dan banyak edges yang berkaitan juga menunjukkan ketertarikan antara pengguna dengan topik yang sedang dibahas.

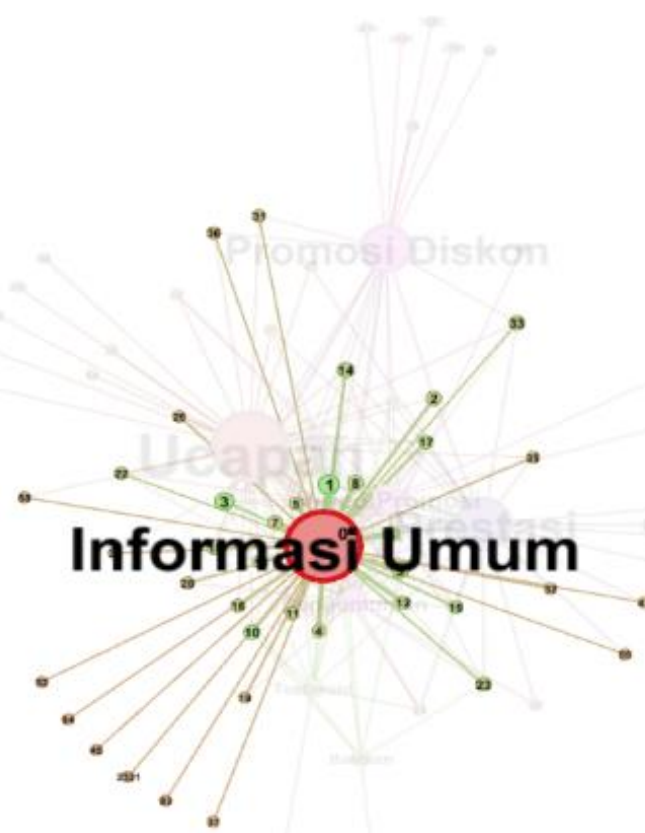

Gambar 4. Cluster terbentuk dari informasi umum 
Pada cluster di atas, terbentuk beberapa nodes dan edges. Jumlah nodes yang didapatkan berjumlah 39 nodes dan edges.Semakin panjang edges yang terbentuk, maka menunjukkan semakin banyak jumlah likes dan comment yang dihasilkan.

Gambar 5. Cluster terbentuk dari pengumuman

Pada kedua gambar diatas menampilkan cluster terbesar dan terkecil yang terbentuk dari fanpage Universitas Bina Darma Palembang. Terdapat 2 topik bahasan, yaitu Informasi dan Pengumuman. Terlihat jelas perbedaan signifikan yang terbentuk antara kedua cluster. Pada cluster informasi banyaknya edges dan besarnya node yang terbentuk menunjukkan besarnya antuasisme user terhadap topik tersebut, sedangkan pada cluster pengumuman hanya memiliki beberapa edges dan besar node yang kecil. Bukan hanya itu saja, pada fanpage Universitas Bina Darma ini terbentuk 7cluster yang sama pentingnya. 7 cluster tersebut antara lain: Ucapan, Prestasi, Video Promosi, Seminar, Promosi Diskon, Testimoni, dan Bantuan. Dari 5 cluster ini dapat digunakan sebagai referensi untuk melihat tingkat ketertarikan user terhadap suatu topik yang sering dibahas dalam fanpage. Cluster Ucapan dan Prestasi termasuk kedalam 3 cluster terbesar yang dapat terbentuk. Seperti pada gambar di bawah ini : 


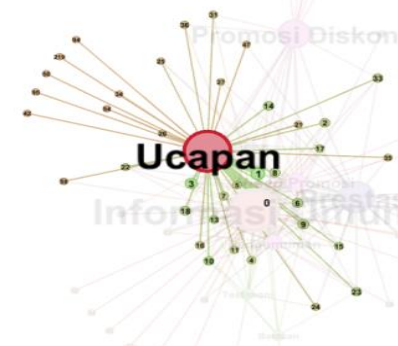

Gambar 6. Cluster terbentuk dari ucapan

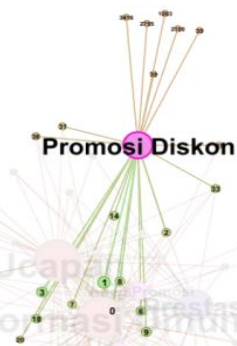

Gambar 8. Cluster terbentuk dari promosi diskon
Gambar 7. Cluster terbentuk dari prestasi

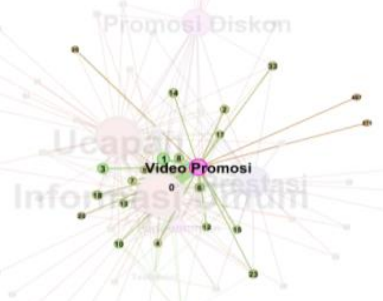

Gambar 9. Cluster terbentuk dari video promosi

\section{2) Visualisasi data pada grup facebook}

Pada saat penelitian ini dilakukan, grup Universitas Bina Darma Palembang telah memiliki pengikut sebanyak 3.084 orang dan di-handle oleh admin sebanyak 5 orang. Pada gambar 4.2 menunjukkan visualisasi data dari 100 postingan teratas pada grup Universitas Bina Darma Palembang. Dapat terlihat dengan jelas pada gambar tersebut bahwa cluster yang dapat terbentuk sebanyak 4 buah. Berbeda dengan visualisasi data cluster fanpage Universitas Bina Darma, disini cenderung memiliki 2 
https://journal-computing.org/index.php/journal-cisa/index

buah cluster yang signifikan. Visualisasi data grup Universitas Bina Darma menunjukkan karakteristik user yang lebih menonjol ke sebuah topik bahasan.
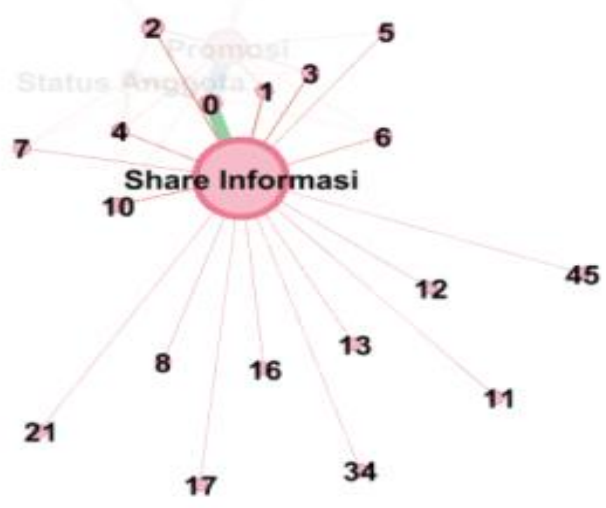

Gambar 10. Cluster terbentuk dari share informasi

Ucapan

Gambar 11. Cluster terbentuk dari ucapan grup

Pada hasil visualisasi data grup official facebook Universitas Bina Darma Palembang di atas, terdapat sejumlah nodes dan edges yang terbentuk. Nodes yang didapat sebesar 27 nodes dan jumlah edges yang didapat 
https://journal-computing.org/index.php/journal-cisa/index

sebesar 41 edges. Setiap nodes bisa memiliki lebih dari 1 edges menyesuaikan keterkaitan antar modul yang terbentuk. Di bawah ini adalah jumlah nodes dan edges yang terbentuk.

\begin{tabular}{|l|l|}
\hline Context $\times$ & \\
\hline Nodes: 27 \\
Edges: 41 \\
Undirected Graph \\
\hline
\end{tabular}

Gambar 12. Jumlah nodes dan edge grup facebook UBD

Pada kedua gambar diatas menampilkan cluster terbesar dan terkecil yang terbentuk dari grup Universitas Bina Darma Palembang. Terdapat 2 topik bahasan, yaitu Share informasi dan Ucapan. Terlihat jelas perbedaan signifikan yang terbentuk antara kedua cluster. Pada cluster informasi banyaknya edges dan besarnya node yang terbentuk menunjukkan besarnya antuasisme user terhadap topik tersebut, sedangkan pada cluster pengumuman hanya memiliki beberapa edges dan besar node yang kecil. Topik share informasi sangat mendominasi pada cluster yang terbentuk sehingga terlihat jelas yang paling menunjukkan ketertarikan pada suatu topik. Selain kedua cluster diatas, terbentuk juga 2 cluster lainnya menunjukkan tingkat ketertarikan user pada suatu topik bahasan. Adapun 2 cluster yang terbentuk tersebut adalah Promosi dan Status Anggota. Pada 2 cluster ini dapat terlihat saling berkaitan satu sama lainnya. Dan dapat menjadi bahan referensi untuk melihat seberapa besar interaksi antar anggota grup tersebut.

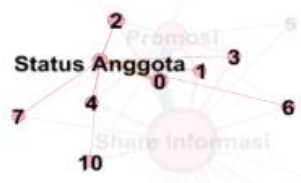

Gambar 13. Cluster terbentuk dari status anggota 


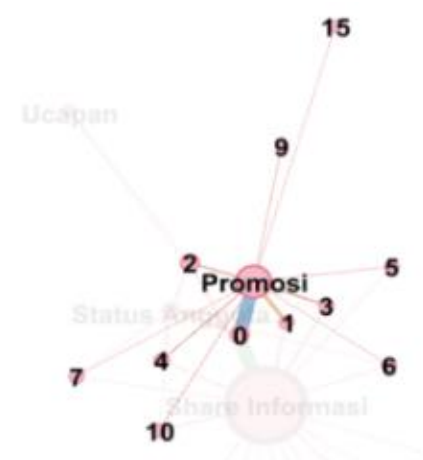

Gambar 14. Cluster terbentuk dari promosi

\section{KESIMPULAN}

Berdasarkan pembahasan di atas, terdapat beberapa point utama dalam hasil penelitian ini:

1) Pada data yang dihasilkan fanpage official facebook Universitas Bina Darma Palembang, kecenderungan kebiasaan pengguna lebih condong ke topik bahasan Informasi Pengumuman akademik yang dapat diakses mahasiswa. Sedangkan untuk calon mahasiswa, mereka cenderung menyukai topik bahasan Informasi mengenai promosi potongan harga.

2) Pada data yang dihasilkan grup official facebook Universitas Bina Darma Palembang, tingkat kecenderungan kebiasaan pengguna lebih tertarik kepada informasi penting yang dapat menunjang kegiatan perkuliahan di Universitas Bina Darma Palembang serta status yang dibuat juga dapat meningkatkan semangat antusiasme anggota grup.

\section{DAFTAR PUSTAKA}

[1] Boyd, D. M, Ellison, N. B. "Social network sites: Definition, history, and scholarship". Journal of Computer-Mediated Communication, 13(1), article 11, 2007.|socialcapitalgateway.org.(2011, July 1). . 
https://journal-computing.org/index.php/journal-cisa/index

[2] Heidemann, J., Klier, M., \& Probst, F. "Online social networks: A survey of a global phenomenon". Computer Networks, 56(18), 3866$3878,2012$.

[3] Viswanath, B., Mislove, A., Cha, M., \& Gummadi, K. P. "On the evolution of user interaction in Facebook. Proceedings of the 2nd ACM Workshop on Online Social Networks" - WOSN '09, 37. 2009.

[4] Rohman, Abdul, Ardani Yustriana Dewi, Kemas M. Irsan Riza, and Takdir. "Sosial Graf untuk Visualisasi Data Facebok Menggunakan Visual Interaction System (Vis.js), 2014.

[5] Aggarwal, Charu C. Social Network Data Analytics. Springer, 2011.

[6] Setatama, M. S., \& Tricahyono, D. Implementasi Social Network Analysis dalam Penyebaran Country Branding "Wonderful Indonesia." 2(2), 14, 2017.

[7] Dian Puteri Ramadhani. "SOCIAL NETWORK ANALYSIS - CHAIN NETWORK TWITTER RIDWAN KAMIL”, 2016. 